\title{
Personal reflections on anti-racism education for a global context
}

\author{
George J. Sefa Dei
}

OISE, University of Toronto, Canada

$\mathrm{I}$

N THIS ESSAY, I REFLECT ON ANTI-RACISM AS A DISCOURSE AND PRACTICE, as well as ways to bring critical conversations to race. We do not live in a post-racial context; it is a myth and illusion to hold to a contrary view. Events such as Trayvon Martin's murder case and the silencing around race, not to mention the open disrespect shown to a President supposedly elected in a post-racial context in the US, should demonstrate that race is far from being irrelevant or transcended. We come to understand the significance of race when the public view of Martin's murderer is split along lines of race: whites largely believing his innocence and insisting race was not a factor, while blacks and other racial minorities were largely convinced of George Zimmerman's guilt and hold a deep conviction that race was a factor. While it is through the social media that the outcry/pressure to arrest Zimmerman was generated, we can still be critical. The failure of the public, and of opinion makers, to use the moment to speak about race in society is itself constitutive of the silencing of race. The unspeakability of race clearly shows its significance. Of course, there must be nuanced readings of race, but I would add that this has always been the case. Race has never been all about skin colour nor thought of exclusively along the lines of a black-white duality. Skin colour is a critical aspect of any discussions on race, but it is not the only measure or reading of race identity. It is unfortunate that those who highlight the saliency of skin colour are often heard as simply seeing race as just about skin colour, or rejecting the intersectionality of our multiple identities. We must not confuse the desire to articulate the ways skin color constitutes rewards, privilege, and also punishment for different peoples to mean race essentialism.

Race has been about identity and identity formation, as well as a key principle of social organization (Omi \& Winant, 1993). Race and anti-racism education is a major task and responsibility for the contemporary educator and learner. In the following discussion, I allude to a collective in arguing that we must all take 
education seriously. This is because education either does something to you, or it does something for you. Education can be misdirected to constitute "miseducation." We can deny our true sense of self and the collective and how we are implicated in systems of domination and oppression. We can lose a deep sense of our shared humanity and the collective responsibilities that reside within it, and, as consequence, miss an opportunity to create a better future for all. Fortunately, through education we can gain critical consciousness of ourselves and of our place in communities. While education alone is not enough to address the dynamism of racisms and social oppressions (we need policies, personal and collective action, and so forth), I believe in the power of education and ideas to ignite community transformation. Education can help young learners to develop interrogative voices to speak about social oppressions and relations of domination. Their self-efficacy as critical thinkers and their capacity for resistance against hegemonic systems and institutions are nurtured. We can use such knowledge and action-oriented pedagogies to challenge privilege and power and to subvert the status quo. Through critical anti-racism education, we are able to clarify the functions of white power/privilege, and how it masquerades as normal, universal, reasonable, and natural to the extent that those punished by such power may even develop fantasies, desires, and aspirations of whiteness.

Without a doubt, education has a role to play in meeting the challenges and possibilities of diversity and difference. In beginning this process, education must be able to engage race and social difference as intrinsic to the identities and lived experiences of learners. This is the crux of anti-racism education. In fact, a long time ago (Dei, 1996), borrowing from the pioneering ideas of earlier anti-racist scholars in Britain and Canada (for example, Barry Troyna, Enid Lee, and Barbara Thomas), I defined anti-racism education as an action-oriented educational practice to address racism and the interstices of difference (such as gender, ethnicity, class, sexuality, ability, language, and religion) in the educational system. Race powerfully implicates and orients schooling, and any education that sweeps race under the carpet is a miseducation of the learner. I will not devote the limited space of this paper to engage the scholarly debates and contentions around the race concept. Suffice to say, racism makes race real and so we must deal with both race and racism as tangible, living, and operative things in/over our world. We cannot address racism without acknowledging the scholarly, conceptual, and practical understandings of race (see Omi \& Winant, 1993). Race has political merits, material consequences, and profound social effects. Race demarcates life chances. Thus, race is neither an illusion nor a myth. It is real and alive in the everydayness of racism, and is embedded in the very foundations of our society and social structures. I understand the idea of race, not as an objective human condition, but more as a subjective identity marker and lived experience that exceeds the limits of scientific, natural, fixed, and bounded categories. Yet, race speaks of socio-historical processes and human social condition. It is for these reasons that we need anti-racism to challenge the full effects of race and racism. Centering questions of race and racism in schooling means bringing to the fore broader questions about colonialism, European imperialist expansion unto Indigenous lands and territories, and the discretionary use of white power and privilege through the sanctioning of 
institutions to claim a false sense of entitlement.

Fanon (1967a) challenges the idea that racism is "a constant of the human spirit" (p. 41) and argues instead that, in fact, colonialism and racism are intricately linked and they both feed on each other. To him, colonialism cannot exist without imperialism to politically, militarily, culturally, and economically support it. Fanon would go on to argue that "colonial racism is no different from any other racism" (p. 88) and that "European civilization and its best representatives are responsible for colonial racism" (p. 90). The inferiority complex of the colonized subject does not predate colonization. This complex "is the correlative to the European feeling of superiority" (p. 93). It is the racist who creates the inferiority of the colonized. The colonial and imperial power of Europe is built on a racist structure, and Europe throughout human history has acted on its racist potentialities. Colonialism has economic, spiritual, material, psychological, and emotional consequences for the colonized. It is not only the seizure/dispossession of Indigenous lands and property and wealth through colonialism, but there occurs a colonization of the mind and perversion of the values of Europe as superior to those of the colonized/Indigenous worlds. The task of antiracism is to link the material, psychological, spiritual, and economic consequences of the colonialism-racism dialectic and to devise anti-racist strategies that empower colonized peoples globally to challenge/resist/fight ongoing colonizations and racisms that deny their basic humanity. Anti-racist education would challenge this false sense of superiority and unearned white privilege, and help restore the basic humanity of the colonized body.

Increasingly so, we need anti-racism education that moves beyond borders and boundaries to implicate global communities. There is a need for additional perspectives to inform critical dialogues on anti-racism education. For educators of today, important first steps might include understanding the dictates of global anti-racist education and what strategies and efforts (pedagogically, instructionally, and communication-wise) can be put in place to ensure equitable and effective outcomes for all learners. There must be an understanding of global anti-racist education that moves beyond some merely intellectualizing transformative projects to concretely engage educational practices that help subvert colonial and racist relations and power hierarchies of conventional schooling. Such education must subvert the assumed normalcy and many of our privileged "taken for granted assumptions." However, bringing the "global" into such discussions is tricky because of the cultural, political, and intellectual baggage often associated with the term. As I have noted elsewhere (Dei 2013a), dominant conceptions of global education quickly tout such virtues of a) the global interdependence of our worlds and communities; b) commitment to fundamental freedoms and rights of all peoples; c) acknowledging cultural diversity and tolerance of intercultural differences; and d) the belief in the efficacy and power of individual action by the learner (Abdi, 2006; Abdi, Puplampu, \& Dei, 2006; Golmohamad, 2008; Mundy \& Manion, 2008; Peters, Britton, \& Blee 2008; Wright, 2011, p. 7). There is nothing wrong with these assumptions. They are laudable if carried through. However, the problem is that these assumptions do not go far enough to fundamentally ensure the true goals and purpose of education. The global 
itself is a site of contention. It is a site where transnational identities are formed, in constant flux and contestations - a stage shaped by the exaltation of particular peoples and ideas, and the historical and ongoing erasure of others. It is a site where power (particularly White power) and privilege is often denied or taken for granted in the meta-narrative of the universal. This often sets the tone for all discussions of the global. The 'global' assumes Western Europe as the transcendent point of human history and intellectuality.

The problematic hegemonic constructions of 'global' and what one can interpret as the theoretical, philosophical, and practical desires to collapse local, national, and international borders and boundaries, and to imagine and re-configure new futures raise some interesting questions of the global: Where is the urgency to deal concretely with power, privilege, and our relative complicities in existing colonial and oppressive relations and the persistent structural inequities that mark the 'global'? Beyond debates of whether there is in fact a global arena of education to speak of, are the questions of who speaks for and shapes this arena, for what purposes, and using what tools to do so. What power relationships have sought to organize the world in the search for harmony and passive integration in the global public sphere? Why is it that global education for the most part has been pursued as a civilizing, colonial, and imperial imposition on everyone, but especially those who do not hold power (Charania, 2011)?

It goes without saying that the current mantra of global education is anchored in the dictates of corporate capital agendas and commercial interests, with its own language of choice, freedoms, privatization, and market ideologies (Kaye, 1992; Peters, Britton, \& Blee, 2008; Portelli \& Solomon, 2001; Portelli \& Vibert, 2001). If we are to dialogue courageously on global anti-racist education and its international dimensions, we cannot fail to ground the conceit of the global and in particular of globalization processes with its imperialistic tendencies. Today, globalization masquerades as an infinite series of universal opportunities. But is it? Globalization speaks of a problematic universality. Many have long wondered if in fact the universal is not an imposed particularity of the West. For example, in the name of globalization, we are increasingly witnessing a brain drain moving from global South to the global North. This describes the ways the global North continues to 'mine' the global South (that is, people in this 'mining' system are reduced to resources which can be extracted and exploited for economic agendas) - a reinvigoration of what is fundamentally the same colonial relationship(s) of centuries past. In the same way, education in the era of globalization is seen as a commodity for export. These commodities are themselves heavily racialized, as African, South Asian, and Latin American labour is increasingly mined and transplanted in Western-serving markets. We must be mindful of business-minded approaches to education, driven by profits more than by concerns of social responsibility. The global South has largely been seen as both resource exporters and potential markets for the reselling of Western goods. Countries of the Global South have become markets for educational models, reforms, and development (for example, NGOs, World Bank/IMF educational policy documents for Africa and the Caribbean, and so on) (Dei, 2012). 
Global anti-racist education should equip the contemporary learner with multiple lenses of critical inquiry of knowledge. This would allow learners to be able to confront issues and questions from multiple stances, noting the different ways of coming to know and understand. There must be an explicit rejection of the hierarchization of epistemologies. Making visible the ways in which Western notions of rationalism and objectivism are predicated on the elevation of an absolute and singular truth, at the expense of other knowledge systems, paves the way to opening up pedagogical space for counter-knowledges to emerge. One of the responsibilities of today's educator is to help learners understand the complexities of society. Global anti-racist education must help promote effective communal living as based on mutual trust and respect for each other, and the sanctity of human life as significant to sustaining the community. Global anti-racist education must help connect learners with their (individual and collective) rights and social responsibilities. Pursuing schooling and education should be conceived of as a communal resource intended for the good of humanity. Identity must be linked with knowledge production to develop critical consciousness among learners of today. Identity is the gradual process of coming to know oneself that is, knowing who one is as a learner and a human being, and how the learner and human subject comes to know about communities and their environments. The subject is multiplex with myriad and connecting identities. Each identity is significant to understand the human life course. Anti-racism education insists on race, gender, class, sexuality, (dis)ability, ethnicity, language, religion, and spirituality, as part of our identities in terms of who we are as persons. It is the interstices of such differences that make us whole as subjects and communities. Education today must assist learners to comprehend such complexities. Education must also be accessible to those who seek to responsibly develop critical consciousness and serve their communities.

We currently live in a moment of rising costs for college and university education - best evidenced by high tuition fees, students accruing huge debts upon completion of their academic programs, and so forth. In addition to the ongoing cuts at colleges and universities, racial minority and working class communities in particular have traditionally had less access to the higher education in the West. So the questions we must ask are: How do we address the question of access to postsecondary education to ensure "excellence" is possible for all students, while also remaining cognizant that equality of opportunity is only possible given the equality of condition? How do we measure and come to achieve such educational excellence by addressing broader questions of equity? That is, how are we making this excellence accessible to a wider section of our communities? Who is represented, how, and why? Who is teaching in our schools, colleges, and universities, and how is our curriculum diversified to ensure that we are telling multiple stories? How are we making the knowledge and education relevant to the communities from where we draw our students? Are we making honest and sufficient attempts to provide educational outreach to our communities? How are we getting clear-enough defining our mandate, and the responsibilities that come with that, for educators and schools?

Part of the challenge of decolonized, anti-racist global education should be about making students feel a sense of welcome and a sense of belonging in their educational 
settings. (In the context of anti-racism global education, "decolonization" refers to the ways education is used to rid the world of colonial knowledge hierarchies, that are themselves racialized through the logics of white supremacist thought, in both its historical and ongoing formations). Students must feel empowered to define themselves in terms of who they are, what they are going to do with their education, and what they see as their broader responsibilities to each other and to their communities. All students should see themselves in a curriculum that broadly includes textbooks and teaching methods, as well as the whole culture, environment, and the socioorganizational lives of schools.

At the same time, we cannot speak of decolonization and of anti-racist education that mobilizes racialized, Indigenous, and Aboriginal communities without frank and honest dialogue on shared implications and responsibilities. Notwithstanding the variegated ways colonialism, imperialism, and racialization has scripted different lives, our resistances show the strengths of collective struggles. The place and particularly the Lands on which we sit offer rich sources of knowledge and, by extension, important implications as to what to do with such knowledges. Land is about acting responsibly and implicating ourselves in the relations of domination and exploitation that take place on occupied or settled Lands. More specifically, anti-racism education demands that we implicate ourselves in the continuum of histories and processes that have led to our residing on particular Lands. Oppressions operate within systems, and they are about shared collective experiences. The fact that such experiences are shared does not mean they are singular. To assert that by accentuating our shared experiences we risk making claims of similar or even singular experiences, is often a selective reading caught in the binary modes of thought so prevalent in Western interpretations and intellectual circles. For me, the question of where one is coming from is critical to my anti-racist practice.

Colonialism and colonization are ongoing everywhere. But there is also a scaled severity of resulting issues and consequences for particular bodies at particular moments in time and space. We must learn to appreciate and understand our divergent experiences and how these shape how we come to know without engaging in the intellectual arrogance of believing in "expert knowers," or, as often alluded to in the Western academy, "rigorous" or "theoretically sophisticated" scholarship. This is not just simply about ways the academy rewards a proximity to whiteness. It is a way of policing and silencing particular discourses from particular bodies. It is also an intellectual arrogance that smacks in the face of Indigenous ways of knowing and its opposition to knowledge hierarchies. We cannot diminish the severity of colonial and imperial oppressions everywhere on an understanding that colonized bodies have now migrated to occupy stolen lands, and are in complicity with the European settler to deny Indigenous peoples their sovereignty. In the Canadian context, settlerhood is the historical practice of land dispossession and land repurposing, physical violence, genocide, and dehumanization of Indigenous peoples. Forced or willing migration to this space does not easily make one complicit in the same ways the original white settlers migrated and advanced the colonial project. Nor does the migration of other racialized and Indigenous peoples level the 'playing field' of settler colonialism and 
its inherited benefits. The racialized migrant subject is certainly implicated in settler colonialism and has a responsibility in Aboriginal peoples' struggle over land and sovereignty everywhere. This fact should not be in dispute, nor do I dispute it here. Yet, as Andrea Smith has said of anti-racism scholars, "we need to look at how 'settlers' are differentiated through white supremacy... without a critique of the settler state as simultaneously also white supremacist, all 'settlers' become morally undifferentiated" (Smith, 2010). I want to take Smith's observation a step further, in arguing that the very term 'settler' is itself too often used to mask the particularity of white supremacist logic and colonial violence, by conflating the myriad differences between racialized migrants and white bodies.

The body of the knowledge producer and the context and tradition within which such knowledge is produced are always very important considerations. Personally, the question of on behalf of what, whom, and why we do our scholarship/intellectual work on anti-racism is germane to my work. So I express more firmly the what, how, and why of affirming Indigenous identities. For example, in my ongoing work on anti-racism and anti-colonial education, I employ Indigenous epistemologies grounded in my African identity that seek to threaten, replace, and reimagine alternatives to colonial thinking and practice. I do this with the hope of contributing to a robust epistemological framework that allows for the coexistence of, and conversation between, multiple epistemes. Through this work I explore three arguments. First, our epistemological frameworks must consider the body of the knowledge producer and the place and context in which knowledge is produced. Second, the anti-colonial is intimately connected to decolonization, and, by extension, decolonization cannot happen solely through Western scholarship. Third, the complex problems and challenges facing the world today defy universalist solutions, and instead can be remedied by multi-centric ways of knowing/doing/being.

By claiming my Indigeneity in a diasporic context, I employ a scholarly entry point for anti-racism that primarily empowers the racially disempowered. (In this way I see diasporic Indigeneity and race as closely related concepts). My politics of race is to evoke what, borrowing from Spivak, I would call a "strategic essentialism of anti-racist practice" to signal the salience of race. I have seen on countless occasions how the fluidity of identities can be unwittingly deployed to counter the salience of race. This salience is about a pre-eminence, not a hierarchy of identity. Similarly, the concept of undifferentiated whiteness is deployed as a conceptual tool to dismantle white supremacy. I, therefore, seek to affirm essentialized racial/Indigenous identities to challenge white supremacist underpinnings. But beyond the self, we must move to a political collective action for organized change.

I would like anti-racism to broach the question of knowledge production in the (Western) academy more forcefully, by situating Indigenous ways of knowing from around the world in our practices. I would not spend too much time responding or writing back to critiques to infantilize or engage in the primitivization of Indigenous knowledges. In fact, as many others have rightly observed, critiques of the Indigenous and particularly Indigenous knowledge has less to do with a supposed lack of theoretical sophistication. It has more to do with how such bodies of knowledge sit with 
bodies of privilege (Battiste \& Henderson, 2000). These dominant bodies think they must control, legitimize, and validate all knowledge production and theory produced in/by the academy. A clear example is when Eurocentric standards are applied to measure the worth of Indigenous knowing, such that knowledge is only legitimate if it is pursued in terms acceptable to the dominant (Andreotti, Ahenakew, \& Cooper, 2011). For racially oppressed scholars, our anti-racism should be about exercising our intellectual agencies by offering Indigenous-centred and anti-racist informed standpoints that help subvert an aggressive ideology that seeks to monopolize intellectual space. We must continually ask: How is it that Europe has time and again continually succeeded in inserting and asserting itself onto the African, Asian, and Aboriginal realities (Asante, 2013)? We must also challenge the problem of viewing Indigenous knowledges as a racial and colonial subset of knowledge. Anti-racism engagement of knowledge is to note that there will be intellectual resistance to seeing ourselves in certain conversations, but to also be bold in naming our implications and responsibilities (for example, race, Indigeneity, and colonization). We are punished for naming Indigeneity, for colonialism, and for remembering our histories (hooks, 1989). Indigeneity is about the power of historical and cultural memory. It is about resisting the push to forget and to erase colonial occupations and white colonial settlerhood on global Indigenous peoples' Lands.

I want to address the politics of claiming space and what a former student in one of my classes at OISE/UT calls the "politics of territoriality" (Abraham, 2010). To claim space is a political act. Not every space is easily accessible. We have gate-keepers who not only discipline unwanted bodies who show up in guarded spaces, but also use their power and privilege to open the space to particular bodies. The racialization of space has been a subject of critical discussion in anti-racism (as explored by Razack, 2002, among many others). For anti-racism work, we need to focus on how racialized bodies not only resist such closure, but also engage in transformative work when they come to claim spaces traditionally off-limits to them. These politics demand that we both continue and move beyond fighting to keep spaces and doors open. It is also about asking ourselves what to do when we come into such spaces. We cannot simply insist on our presence in such spaces. We must pursue a radical politics that transforms our institutions by using our presence to intervene, disrupt, and implement alternatives. We have to assert voices that upset and subvert the status quo. We must become a voice of difference and translate any false sense of entitlements into meaningful political action for change. There must be a hegemonic rupturing of the space that includes articulating counter and oppositional voices, Indigenous knowledges, and anti-colonial praxis. We must challenge the temptation to look to the dominant to seek validation, acceptance, and legitimacy in still-colonized spaces of knowledge production and education. Such practices of looking to the dominant can be wounding emotionally, spiritually, and to the psyche. Fanon (1967b) long ago cautioned against a colonial mimicry that disclaims our authentic souls and dismembers selves. Any sense of complacency and feeling that we have entered or come into these spaces through our individual hard work/merit or excellence must be challenged.

Opening doors has been a historic struggle for racialized bodies and our 
communities, just as it has been for women, LGBTQ people, linguistic and religious minorities, and working class communities. Through resistance, excluded bodies have found some measure of inclusion. But the struggle for inclusion is far from over. There are concerns circling the question of inclusion, such as: For what ends and purposes is it sought? How is our inclusion subversive of the status quo? In effect, the politics of coming into a given space requires an awareness of the histories of struggles and the responsibility to uphold the goals and dreams of the pioneers who fought to open doors. Anything less is betraying their cause and associated sacrifices. We should also avoid being seduced by false hopes that because we are included, the struggle has been won. In fact, inclusion is just the beginning. It is important to always assess what happens to different bodies when they come into previously exclusionary spaces. For example, how are they sustained and how are their voices, experiences, and histories taken up as part of everyday learning and academic inquiry? The politics of coming into an exclusionary space for the subordinate is to subvert whiteness (and white power) and its rationality for dominance. It requires that we champion community causes rather than be preoccupied with our individual advances and accomplishments. It demands that we do not become aloof from our communities, estranged from the practical struggles we remain part of, and that we not be enticed to study our communities from a distance (Dei, 2013b). Such intellectual closeness to struggle and emphasis on embodied knowledges that flow from lived experience is precisely what anti-racism is all about.

\section{Acknowledgements}

I would like to thank Aman Sium and Eunice Chow - graduate students of the Ontario Institute for Studies in Education, University of Toronto - for reading, editing, and commenting on drafts of this paper.

\section{References}

Abdi, A. A. (2006). Culture of education, social development, and globalization: Historical and current analyses of Africa. In A. A. Abdi, K. P. Puplampu, \& G. J. S. Dei (Eds.), African education and globalization: Critical perspectives (pp. 13-30). Lanham, MD: Rowman \& Littlefield Publishers.

Abraham, A. (2011, Fall). African and Western knowledge synthesis. (Unpublished course paper, SES 1924H: Modernization, Development and Education in African Context). Department of Sociology and Equity Studies, Ontario Institute for Studies in Education of the University of Toronto.

Andreotti, V., Ahenakew, C., \& Cooper, G. (2011). Epistemological pluralism: Ethical and pedagogical challenges in higher education. (Unpublished paper). 
Asante, M. (2013, August 7). Decolonizing universities in Africa: An approach to transformation. Keynote address at the International Conference of African Scholars, Nelson Mandela Metropolitan University, Port Elizabeth, South Africa.

Battiste, M., \& Henderson, J. Y. (2000). What is indigenous knowledge? In M. Battiste \& J. Y. Henderson, Protecting indigenous knowledge and heritage (pp. 35-56). Saskatoon, SK: Purich.

Charania, G. (2011). Grounding the global: A call for more situated practices of pedagogical and political engagement. ACME: An International EJournal for Critical Geographies, 10(3), 351-371.

Dei, G. J. S. (1996). Anti-racism education: Theory and practice. Halifax, NS: Fernwood Publishing.

Dei, G, J. S. (2012, April 13-17). Interrogating global citizenship education from an indigenous knowledge perspective. Paper presented on the panel session on Re-imagining the 'global citizenship' discourse: A view from the contexts of developing countries, Annual Meeting of the American Educational Research Association (AERA), Vancouver, BC.

Dei, G. J. S. (2013a, forthcoming). Global education from an 'indigenist anti-colonial' perspective. Journal of Contemporary Issues in Education.

Dei, G. J. S. (2013b, under review). The African scholar. Journal of Black Studies.

Fanon, F. (1967a). Toward the African revolution. New York, NY: Grove Press/Monthly Review Press.

Fanon, F. (1967b). Black skin, white masks. New York, NY: Grove Press.

Golmohamad, M. (2008). Global citizenship: From theory to practice, unlocking hearts and minds. In M. A. Peters, A. Britton, \& H. Blee (Eds.), Global citizenship education: Philosophy, theory and pedagogy (pp. 519-533). Rotterdam, Netherlands: Sense Publishers.

hooks, b. (1989). Talking back: Thinking feminist, thinking black. Boston, MA: South End Press.

Kaye, H. J. (1992). Education and democracy: Should the fact that we live in a democratic society make a difference in what our schools are like? In J. L. Kincheloe \& S. R. Steinberg (Eds.), Thirteen questions: Reframing education's conversation (pp. 125-134). New York, NY: Peter Lang.

Mundy, K., \& Manion, C. (2008). Global education in Canadian elementary schools: An exploratory study. Canadian Journal of Education, 31(4), 941-974.

Omi, M., \& Winant, H. (1993). On the theoretical concept of race. In C. McCarthy \& W. Crichlow (Eds.), Race identity and representation in education (pp. 3-10). New York, NY: Routledge.

Peters, M. A., Britton, A., \& Blee, H. (Eds.). (2008). Global citizenship education: Philosophy, theory and pedagogy. Rotterdam, Netherlands: Sense Publishers.

Portelli, J. P., \& Solomon, R. P. (2001). Introduction. In J. P. Portelli \& R. P. Solomon (Eds.), The erosion of democracy in education: From critique to possibilities (pp. 15-28). Calgary, AB: Detselig Enterprises, Ltd.

Portelli, J. P., \& Vibert, A. B. (2001). Beyond common educational standards: Towards a curriculum of life. In J. P. Portelli \& R. P. Solomon (Eds.), The erosion of democracy in education: From critique to possibilities (pp. 63-82). Calgary, AB: Detselig Enterprises, Ltd.

Porfilio, B., \& Malott, C. (Eds.). (2008). The destructive path of neoliberalism: An international examination of urban education. Rotterdam, Netherlands: Sense Publishers. 
Razack, S. H. (Ed.). (2002). Race, space and the law: Unmapping the white settler society. Toronto, $\mathrm{ON}$ : Between the Lines.

Smith, A. (2010). Indigeneity, settler colonialism, white supremacy. Global Dialogue, 12(2). 
